\title{
Reflecting on being ready to go to war
}

BOOK TITLE:

Reflections on war:

Preparedness and consequences

\section{EDITORS:}

Thean Potgieter

Ian Liebenberg

ISBN:

978-1-920338-84-8

\section{PUBLISHER:}

SUN Press, Stellenbosch, R220

\section{PUBLISHED:}

2012

\section{REVIEW TITLE:}

Reflecting on being ready to go to war

\section{REVIEWER:}

André Wessels

\section{AFFILIATION:}

Department of History, University of the Free State, Bloemfontein, South Africa

\section{EMAIL:}

wesselsa@ufs.ac.za

\section{POSTAL ADDRESS:}

Department of History, University of the Free State, PO Box 339, Bloemfontein 9300, South Africa

\section{HOW TO CITE:}

Wessels A. Reflecting on being ready to go to war. S Afr J Sci. 2013;109(7/8), Art. \#a0026, 2 pages. http://dx.doi.org/10.1590/ sajs.2013/a0026

(C) 2013. The Authors

Published under a Creative Commons Attribution Licence.
Has there ever been a time when people have not been engaged in, or traumatised by war? Will there ever be peace? In the course of Queen Victoria's reign of 64 years (1837-1901), the British Army was involved in no fewer than 230 wars, campaigns and punitive expeditions. ${ }^{1}$ In the wake of the two catastrophic world wars of the 20th century, the Cold War between the world's two superpowers did not prevent hot wars from breaking out (the drawn-out war in Vietnam, and several liberation struggles and/or civil wars in Africa being pertinent examples). Regrettably, the end of the Cold War did not lead to the proverbial 'heaven on earth'.

Since the end of the Cold War (ca 1990), millions of people have died in conflicts around the globe, with most of the fatalities occurring in Africa: an estimated 3658000 dead in Zaire/the Democratic Republic of the Congo since 1996, at least a million dead in the Sudan, 365000 dead in Somalia since 1991 and 196000 dead in Algeria from 1992 to $1999 .{ }^{2}$ It is unfortunate, but a fact, that the Four Horses of the Apocalypse - War, Famine, Pestilence and Death - are still rampant in Africa, with all the concomitant destruction, displacement of hundreds of thousands of people, and trauma. How does one prevent war? Or, if war is (apparently) inevitable, how does one prepare for war? When is one truly ready for war?

In their latest publication, the Centre for Military Studies (CEMIS) at the Stellenbosch University's Faculty of Military Science (usually referred to as the South African Military Academy), has reflected on being ready to go to war. Under the guidance of Thean Potgieter and lan Liebenberg as editors, 13 other contributing authors (all experts in their respective fields of study) have been brought together to produce a thought-provoking publication - Reflections on War: Preparedness and Consequences. As one of the 27 South African and international peer reviewers, Professor Veronica Usacheva (Institute for South African Studies, Russian Academy of Sciences, Moscow) correctly points out (in the blurb on the back cover) that the authors have indeed succeeded in covering a broad range of issues in the discourse on war and other forms of conflict. In various chapters the crucial links between theory, strategy and objectives in war are investigated. The relevance of theory for understanding and explaining the timeless and constant phenomenon of war is indicated, and special attention is drawn to when and how a country should not go to war.

In 15 chapters, this book explores when it is possible for nations or countries to go to war, or to sustain armed conflict. Many other relevant issues are also covered; for example, the consequences of war, the need for foresight when considering utilising military force or projecting military power towards other countries or communities, the prevention of conflict, and what 'lessons' have been 'learned'. Throughout, many historical examples are used to contextualise the arguments that are used and the conclusions that are made, but contemporary examples are also applied to serve as a warning about how states should do business in our challenging times. The reader is also clearly informed about the risks inherent in sustaining armed conflict.

Space limitations do not allow for a detailed overview of the various chapters. (For an excellent review in this regard, see the book's Introduction.) Suffice it to say that the chapters deal with the crucial link between theory, strategy and objectives (by Thean Potgieter); the theory and practice of military preparedness in history from the birth of modern conventional warfare to the contemporary age of internal conflict and asymmetrical warfare (Deon Visser); the experiences of the Union of South Africa and South African society during World War II (Fankie Monama); militarised politics, the economic consequences and the implosion of state legitimacy under apartheid (lan Liebenberg and Francois de Wet); the nature and challenge of preparing military personnel for their task in the defence, military and fighting domains (Abel Esterhuyse); the thorny issue of the military readiness of South Africa's armed forces (Francois Vrey); the fact that casualties are a given when armed forces are deployed (Thean Potgieter and Shadrack Ramokgadi); geography and the conduct of war (Hennie Janse van Rensburg and Hennie Smit); intelligence, defence planning and the conduct of war (Benjamin Mokoena); logistics as 'the sinews of war' (Thean Potgieter and Ishmael Theletsane); the gravity of the decision by South Africa to return its soldiers to border duty in 2010 to replace the police border contingents (Francois Vreÿ); the notion of when a war can be considered just (Pieter Brits and Michelle Nel); the pivotal role played by public opinion in the decision of political decision-makers to go to war (Makatipe Charles Kgosana); the performance of four economies - South Africa, Nazi Germany, the USA and the UK - before and during World War II (Francois de Wet and lan Liebenberg); and the far-reaching developments in North Africa during 2011, with special reference to Libya (lan Liebenberg).

What are the conclusions? As the editors aptly state in the last paragraph of their book (p. 289):

This study demonstrates that understanding conflict and war is not only about battles and campaigns. We must also consider careful and thorough preparations, before utilising armed force. The central message that appeared is therefore unequivocal throughout - be careful of 'war', rather prevent it than enter it, but understand what the deployment of military power will demand.

The editors - and their contributing authors - have admirably succeeded in their task, and have produced a study on war, its preparedness and consequences that can serve as a standard textbook for anyone interested in this topic.

From the brief review and evaluation above of the publication's content, it should be clear that Reflections on War is a comprehensive work. It draws together a multitude of insights from military history, sociology, international legal theory, the management sciences, international politics, and international political economy, thereby emphasising the transdisciplinary approach taken by the editors. The end product is indeed a noteworthy work in the field of the military sciences, and, to a large extent, fills the gap that has existed in the sphere of discourse on 'going to war' or 'not going to war'. The book is relevant within the African context, but can also be of value to military scholars 
and experts further afield - anyone who has to reflect on war, and who has to take into account the challenges of preparing for war. Moreover, the publication also poses warnings and raises critical questions for the future.

The South African National Defence Force's involvement in the Central African Republic, and in particular the 'battle in Bangui' (22-24 March 2013) which left 13 South African soldiers dead and 27 wounded (of whom 2 have since died), as well as the South African government's decision to take part in a multi-national military mission in the Democratic Republic of the Congo, has placed South Africa's defence force in the spotlight, together with questions as to its preparedness to take part in peace-keeping and other missions. Reflections on War, published before these events took place and before certain decisions were taken, clearly points out the dangers and moral dilemmas of going to war, or placing one's troops in harm's way.
This excellent scholarly publication should be compulsory reading matter for all officers in the South African National Defence Force (and other defence forces), and for students of war studies, military history and related subjects, but should also find wide appeal among military history enthusiasts, people who follow military events and journalists, as well as among general readers who are interested in military matters. The editors, as well as the contributing authors, are to be congratulated for work well done. The book is highly recommended.

\section{References}

1. Farwell B. Queen Victoria's little wars. New York: Harper \& Row; 1973. p. $364-371$.

2. The 2013 chart of conflict. In: Hackett J. The military balance 2013. London: The International Institute for Strategic Studies; 2013. 